\title{
In memory: Professor Gad Loebenstein 1929-2018
}

\author{
Abed Gera \\ Published online: 12 April 2018 \\ (C) Springer Science+Business Media B.V., part of Springer Nature 2018
}

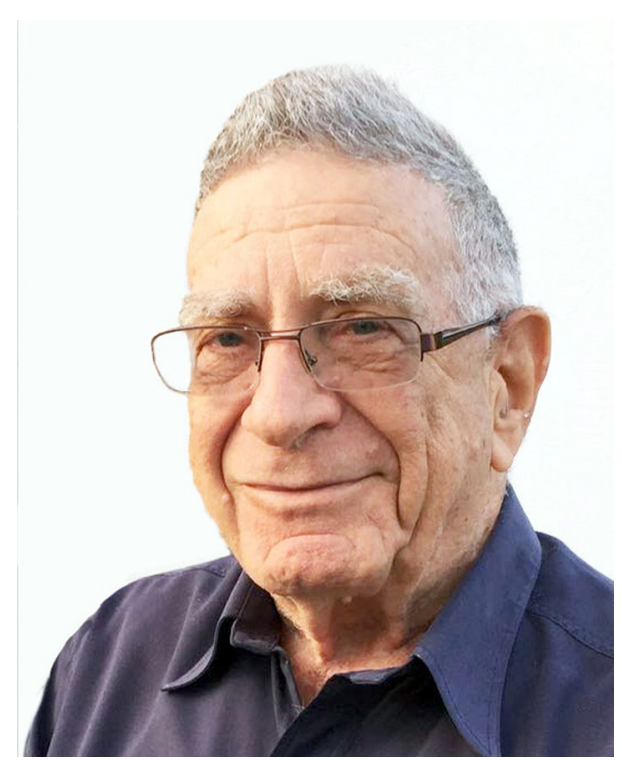

Prof. Gad Loebenstein, aged 89 years old, passed away on Sunday 18 February 2018 in Rehovot, Israel, following a brave battle with cancer. During his last days he was surrounded by loving family and friends.

Gad was born on February 17, 1929 in Berlin, Germany and immigrated to Israel in 1939 with his parents Moritz and Marie Loebenstein. He graduated from the Hebrew University of Jerusalem (HUJ), in 1954 and earned a

A. Gera $(\bowtie)$

Plant Protection and Inspection Services, Ministry of Agriculture and Rural Development, Bet-Dagan, Israel

e-mail: AbedG@moag.gov.il
Doctor of Philosophy (Ph.D) from HUJ, in 1960. Gad, was a plant pathologist who played a leading role in combating plant viral diseases in Israel and worldwide.

Gad was an influential pioneer of plant virology research. He established and headed the Department of Plant Virology at the Agricultural Research Organization, ARO, Volcani Center, Israel, (1960-1994), served as both Head of the Plant Protection Institute (19671974) and Director of the ARO, Volcani Center, and served as the Chief Scientist of the Ministry of Agriculture, Israel (1981-1986). He served as a Professor at Tel Aviv University and the HUJ, since 1973 and a visiting professor at the University of Birmingham, UK (19741975). He taught classes and conducted research in his field of expertise, plant virology. He was active in supporting the journal 'Phytoparasitica' (The Israel Journal of Plant Protection Sciences), as it was known in its early days. 'Phytoparasitica' was initially published by the ARO, Volcani Center, until 1992.

Gad was an active member of several scientific societies: the Science council, Istituto Fitovirologia Applicata, Torino, Italy, (1981-1986); served as a board member of the Binational Agricultural Research and Development (BARD), Bet Dagan, Israel, (19821986) and the Managing Director of Serum Tech, Rehovot, Israel (1996-1999), and a board member of Yakhin/Hakal, Tel Aviv (1997-2002),

Gad served as an advisor of the World Bank Mission to Nigeria. He was an elected member of the Kazakh Agricultural Academy (1997) and served as a member of the Virology Committee of the American Phytopathology Society (APS), St. Paul (2001-2004). He was 
honored as an APS Fellow in 1989, an award that recognizes distinguished contributions to plant pathology and/or the society. He was a member of the Israeli Phytopathology Society (IPS - founder and its first president) and correspondent of the German Phytomedizische Gesellschaft. He was the author of more than 250 reviewed scientific and technical publications, and edited or co-edited eight books on plant virology. Many relate to his research subjects on viruses of sweet potato and potatoes; rapid propagation of potatoes for preparing certified potato tuber seeds; natural resistance mechanisms of plants to viruses; interaction between viruses and their vectors, and epidemiology and control of viruses of specific crops. These include vegetables, citrus and a wide range of flower and ornamentals crops. Gad had a special love for sweet potato and he was undoubtedly one of the most renowned virus epidemiologists of this crop.

Gad was described as an 'editorial genius' for his ability to take drafts of papers and shorten them in half whilst adding invaluable additional points. Gad contributed much to our knowledge of plant virology, both within Israel and abroad, and was a tireless advocate, supporter, and promoter of plant pathology.

As Chief Scientist of the Israeli Ministry of Agriculture, he always stressed the importance of a balance between applied and basic research; field work, 'hands on' approach to research, and deplored the lack of it among so many scientists. He emphasized that it was essential to observe crops and plants in situ to achieve an holistic understanding of the biology and epidemiology of plant diseases. Nevertheless, he was responsible for establishing the Israeli Phytopathology Society (IPS) in 1979, at a time when the applied "biological" aspects of phytopathology were in danger of being swamped by those with more fundamental "biochemical" approaches. This initiative led to the organization of 38 annual IPS meetings and the series continues with the 39th meeting that was held in February, 2018.

Gad has no special 'words of wisdom' to impart as the recipe for personal happiness and fulfilment. However, he did stress the value of having a supportive family and the merits of a long and exciting career in research accompanied with the necessity of taking on the burdens and distractions of administration.

Gad and his students studied local and systemic forms of acquired resistance induced by tobacco mosaic virus in hypersensitive tobacco. The subject of protection against, or interference with, plant virus infection is still a source of puzzlement accompanied with speculations.

I had the privilege to conduct my M.Sc and Ph.D under Gad's supervision, studying the transmission of Cucumber Mosaic Virus by aphids and using the protoplast system to study the resistance mechanism against Tobacco Mosaic Virus. The use of protoplasts for studying plant viruses was a novel technique at that time. Gad was an excellent mentor and a good friend to all, and he maintained long-term relationships with many of those who passed through his lab. He had a dynamic personality and was always full of ideas and enthusiasm for science throughout his career. Much of Gad's research was conducted in collaboration with others who had complementary expertise: colleagues at the ARO, Volcani Center or virologists abroad. He became known to the wider virology community, wrote influential reviews, presented many invited talks, and served as coEditor of the 'European Journal of Plant Pathology' and the 'Journal of Phytopathology'. His achievements motivated a strong contribution to establishing the international reputation of the Volcani Center as a center for plant virus research.

In character, Gad was lively and full of ideas, good company, a dedicated scientist and leader with a strong sense of correctness. He enjoyed life and was proud of his family. He will be remembered for his numerous scientific achievements, leadership, righteousness, and friendship. Within his circle of friends and colleagues, particularly the younger scientists who worked with him, Gad was always held in great affection, regard and respect. Always a kindly and thoughtful 'boss', he frequently put himself out for his younger staff providing advice and help with personal problems.

Gad was a great character in so many ways and will be sorely missed by all those who knew him. He is predeceased by his wife Esther and survived by two daughters, Tamar and Yael, and two sons, Yuval and Rani. 